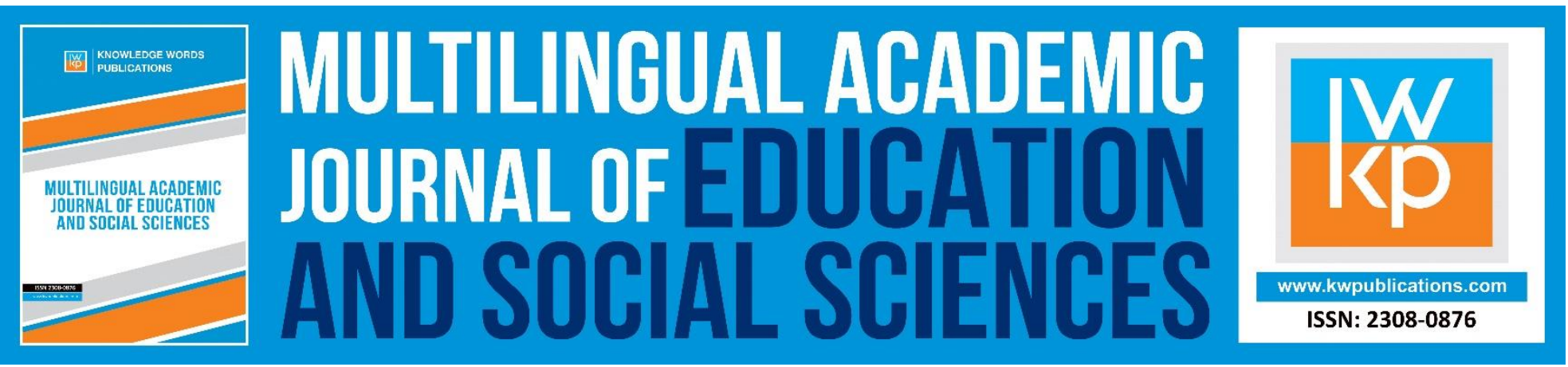

\title{
Social Capital, Collectivism and Development by Ran Bijay Narain Sinha, Janaki Prakashan, Patna, India (2016): Book Review
}

\section{Suman K Singh}

To Link this Article: http://dx.doi.org/10.46886/MAJESS/v6-i1/3769

DOI: 10.46886/MAJESS/v6-i1/3769

Received: 08 August 2018, Revised: 08 September 2018, Accepted: 09 October 2018

Published Online: 21 December 2018

In-Text Citation: (Singh, 2018)

To Cite this Article: Singh, S. K. (2018). Social Capital, Collectivism and Development by Ran Bijay Narain Sinha, Janaki Prakashan, Patna, India (2016): Book Review. Multilingual Academic Journal of Education and Social Sciences, 6(1), 63-65.

\section{Copyright: (c) The Authors 2018}

Published by Knowledge Words Publications (www.kwpublications.com)

This article is published under the Creative Commons Attribution (CC BY 4.0) license. Anyone may reproduce, distribute, translate and create derivative works of this article (for both commercial and non-commercial purposes), subject to full attribution to the original publication and authors. The full terms of this license may be seen

at: http://creativecommons.org/licences/by/4.0/legalcode

$$
\text { Vol. 6, No. 1, 2018, Pg. } 63 \text { - } 65
$$

Full Terms \& Conditions of access and use can be found at https://kwpublications.com/pages/detail/publication-ethics 


\title{
Social Capital, Collectivism and Development by Ran Bijay Narain Sinha, Janaki Prakashan, Patna, India (2016): Book Review
}

\author{
Suman K Singh \\ Professor of Psychology (Superannuated), Bodhgaya, India
}

A model of development that finds equal resonance across societies continues to elude professionals. The much-touted theory that trickle-down effect of economic abundance ensures development in all spheres, is already busted. The Indian paradox proves the point where consistent economic growth exists with incommensurate gains in social development. The inconsistencies of the post-globalization world are increasingly intriguing social scientists of all hues. What is however clearly emerging is the predominance of socio-cultural context within which developmental activities take place, throwing newer challenges for inclusive development models. The present work by R B N Sinha is an attempt to take the discussion forward by exploring a combination of social factors critical to inclusive development in an Indian setting.

Arguing that social capital has critical role in facilitating inclusive development, that has not been examined in an empirical fashion, largely because of western influences on conceptualizing development in India. He undertakes extensive literature review to unravel various facets of social capital as enunciated in social science research to underscore its importance in inclusive development. This part of the book also presents a comprehensive understanding of development emphasizing that development is not possible without the empowerment and involvement of the poor and the marginalized who constitute the majority. To widen the understanding around social capital and development the author brings in an interesting cultural dimension of individualism - collectivism and focusing on Indian brand of collectivism in the entire discussion. Using this knowledge base, a conceptual framework has been developed that social capital is instrumental in inclusive development where collectivism of the respondents plays a moderating role. The moot question that the study raises is whether social capital can be used as a reliable index for development and the extent to which social capital can be predicted by standard of living, education, health etc. Further, the question whether cultural orientation predicts social capital and development, has also been raised.

Using relevant statistical analysis five dimensions of social capital - social cohesiveness, cooperation, trust, acceptance of system and selfishness have been identified. Similarly, cultural orientation has been examined through factors such as familial collectivism, individualism, and 
collectivism and individualism. Development has been observed at two levels, family (economic status, standard of living, educational status and interrelationship) and village (economic, prestige, education and health). Correlation between factors within and between the dimensions has been examined. Stepwise Multiple Regression Analysis of economic development showed cultural orientation, such as familial collectivism, as the most dominant predictor. The components of social capital were considered as independent, indicators of development as dependent, and aspects of cultural orientations as moderators. Conducted in a rural setting the intensive enquiry involved 400 house heads of varied socio-economic and educational background drawn from four villages.

The initial thinking of the author was that social capital shall predict development depending upon the interplay of cultural factors. The findings however suggest that social capital and cultural orientations are not independent and secondly, social capital and cultural orientations are both multidimensional. Familial collectivism and social cohesiveness emerged as the most significant predictors of development both at family as well as village levels.

The study raises a few questions and cautions regrading development of a unitary measure of social capital because of its multidimensionality as also its dynamic nature and form. Conceptual unanimity among researchers about the very concept of social capital is the main drawback in pursuing interest in such an interesting area. 